UDC 330.341 .1

\title{
DIRECTIONS OF FORMATION AND DEVELOPMENT OF INTELLECTUAL CAPITAL OF THE TOURISM INFRASTRUCTURE ENTITIES
}

\section{НАПРЯМИ ФОРМУВАННЯ ТА РОЗВИТКУ ІНТЕЛЕКТУАЛЬНОГО КАПІТАЛУ СУБ'ЄКТІВ ТУРИСТИЧНОї ІНФРАСТРУКТУРИ}

\author{
Biletska Iryna \\ Ivano-Frankivsk Educational and Scientific Institute of \\ Ternopil National Economic University \\ Білецька Ірина Мирославівна \\ доктор економічних наук, доцент, \\ Івано-Франківський навчально-науковий інститут менеджменту \\ Тернопільського національного економічного університету \\ ORCID: https://orcid.org/0000-0002-6906-7161
}

\begin{abstract}
The article is devoted to relevant issues of formation and development of intellectual capital of enterprises that constitute the tourism infrastructure. The purpose of the study is to substantiate the directions and means of formation and development of intellectual capital of the tourism infrastructure enterprises. The author's description of the concept and structure of intellectual capital of an enterprise is given. It is established that intellectual capital of the tourism infrastructure enterprises comprises such basic elements as, first, the company's staff (and their competence characteristics) able to accumulate and generate intellectual creativity, create and commercialize innovations and implement their results in economic practice to form modern logistical and information-technological support for business processes; secondly, the provision of the enterprise with modern equipment and technologies, information, infrastructure for innovation and intellectual-creative activities; thirdly, the extent and effectiveness of the combination of factors of labor and intelligence. It is proved that intellectual capital is a dynamic concept and is close to the intellectual potential. The composition of the tourism infrastructure entities involves tourism companies, accommodation facilities, food facilities, accompanying and communication facilities providing transport, trade, cultural, educational, sports and other services to meet the needs of tourists. The relevance of the formation and use of intellectual capital of the tourism infrastructure enterprises is substantiated. In the current research, the scientific methods of strategic management (for constituting the bases for structuring the purposes of improvement of intellectual capital of the tourism infrastructure enterprises) and the system approach (to substantiation of priorities and tools for improvement of intellectual capital of the tourism infrastructure entities) are applied. The means of formation of intellectual capital of the tourism infrastructure enterprises are determined. Further scientific research in this area concerns the substantiation of economic and mathematical models of intellectual capital using. The practical significance of the research results concerns the ways to increase intellectual capital of the tourism infrastructure and strengthen both the competitiveness and overall economic potential of tourism in Ukraine, which also has a major social effect in meeting the needs of consumers in tourism and recreation services.
\end{abstract}

Keywords: tourism activities, tourism infrastructure enterprises, intellectual capital, formation and development, competitiveness.

Стаття присвячена актуальним питанням фрормування та розвитку інтелектуального капіталу підприємств, які утворюють туристичну інфраструктуру. Метою дослідження є обґрунтування напрямів та засобів фрормування і розвитку інтелектуального капіталу підприємств туристичної інсрраструктури. Надано авторську характеристику поняття та структури інтелектуального капіталу підприємства. Визначено склад суб'єктів, що утворюють туристичну інфраструктуру. Обґрунтовано актуальність фрормування та використання інтелектуального капіталу підприємств туристичної інфраструктури. В процесі дослідження застосовано наукові методи стратегічного менеджменту (для фрормування засад структуризації цілей покращення інтелектуального капіталу підприємств туристичної інсрраструктури) та системного підходу (при обґрунтуванні пріоритетів та інструментів удосконалення інтелектуального капіталу підприємств туристичної інфраструктури). Подальші 
наукові пошуки в цьому напрямі стосуються обґрунтування економіко-математичних моделей в сфері використання інтелектуального капіталу суб'єктів господарювання.

Ключові слова: туристичний бізнес, підприємства туристичної інфрраструктури, інтелектуальний капітал, фрормування та розвиток, конкурентоспроможність.

Статья посвящена актуальным вопросам формирования и развития интеллектуального капитала предприятия, которые образуют туристическую инфраструктуру. Целью исследования является обоснование направлений и средств формирования и развития интеллектуального капитала предприятий туристической инорраструктуры. Предоставлено авторскую характеристику понятия и структуры интеллектуального капитала предприятия. Определен состав субъектов, образующих туристическую инсраструктуру. Обоснована актуальность формирования и использования интеллектуального капитала предприятий туристической инфрраструктуры. В процессе исследования применены научные методы стратегического менеджмента (для фрормирования основ структурирования целей улучшения интеллектуального капитала предприятий туристической инфрраструктуры) и системного подхода (при обосновании приоритетов и инструментов совершенствования интеллектуального капитала предприятий туристической инфраструктуры). Дальнейшие научные исследования в этом направлении касаются обоснования экономико-математических моделей в сфере интеллектуального капитала субъектов хозяйствования.

Ключевые слова: туристический бизнес, предприятия туристической инфраструктуры, интеллектуальный капитал, формирование и развитие, конкурентоспособность.

Problem statement. The processes of globalization, growing openness of the national economy and large capacity of the domestic consumer market have led to high economic attractiveness of Ukraine's tourism and its infrastructure, where significant amounts of capital have been invested and modern foreign management technologies have been imported. This resulted not only in the growth of competition, but also in the monopolization of industry and difficulties in the activities of traditional, less financially viable entities, although important in the context of spatial and structural balance of development and social responsibility of the industry.

The viability of tourism infrastructure enterprises, their further progress, strengthening of competitiveness, effective performance of functions and implementation of their role in the tourism system still depend on the capital factor, but given the current trends of active use of the Internet, IT, e-commerce, etc., they are determined more by labor, in particular highly intelligent one. Intellectual capital becomes a source of accumulation and efficient use of personnel of the tourism infrastructure enterprises, as well as a source for innovations in business processes.

It is necessary to understand that intellectual capital is the key resource of an enterprise, without which neither the client-oriented approach nor an active use of innovations and advanced business technologies are possible. Therefore, the task of formation and effective use of intellectual capital of the tourism infrastructure enterprises becomes relevant.

Analysis of recent research and publications. The basic provisions on the management of tourism enterprises and tourism infrastructure development are sufficiently studied in the works of T. Vasyltsiv, A. Shekhlovych [1], Yu. Migushchenko [2], I. Orlyk [3], O. Vlasyuk [4], R. Lupak [5], A. Golod [6], O. Melnychenko [7], A. Okhrimenko [8], A. Dymchuk [9] and others.

At the same time, domestic enterprises of tourism infrastructure do not implement modern effective management and infrastructure mechanisms for the formation and use of their intellectual capital. The lack of theoretical and applied developments on this issue has necessitated the scientific research in this direction.

The purpose of the article is to substantiate the directions of formation and development of intellectual capital of the tourism infrastructure entities.

The main research material. The adoption of economic, organizational and institutional conditions of a market economy in Ukraine has significantly changed the environment of tourism infrastructure enterprises, as well as the influence of factors determining parameters of competitiveness and prerequisites for development.

The formation of a competitive environment and strengthening of the principles of competition make demands for quality resources, including human resources, as an important component of management at every stage and level of business process.

At the same time, the importance of intangible assets is growing. The objective trends of the current phase of development of the national economies' domestic markets concern the emerging role of innovation and an active introduction of Internet and IT technologies in economic practice.

There is a close relationship between intellectualization and a higher level of socio-economic deve- 
lopment. The combination of artificial and human intelligence, personnel and intangible resources and assets of enterprises is particularly important, since a synergistic effect allows getting a unique resource for the functioning and development of business in the growing information society.

There are a number of dominant features regarding intellectual capital of the tourism infrastructure entities, namely:

(1) provision of a company with personnel (and their competence characteristics), able to accumulate and generate intellectual creativity, create and commercialize innovations and implement their results in business practice to form a modern logistics and information technology support for business processes;

(2) provision of an enterprise with advanced equipment and technologies, information, infrastructure of innovation and intellectual-creative activities;

(3) extent and effectiveness of the combination of labor and intelligence factors.

Intellectual capital of the tourism infrastructure enterprises provides for the formation of intellectual and human capital, as well as the effectiveness of its use for creating and commercializing the results of research and innovation to strengthen competitiveness and increase the efficiency of business processes. Intellectual capital is increasingly becoming one of the most important components in the system of enterprise development, as it is a factor in the formation of quality management staff. It should be considered under a system approach, which allows to manage the processes of its formation, development and using more effectively. Arguments in favor of this are the performance of intellectual capital as a separate subsystem of an enterprise with its own constituents (intellectual and personnel), elements, internal and external relations.

The system of intellectual capital of tourism infrastructure is a set of interrelated elements of economic, organizational, legal, socio-professional, technical and technological nature, as well as measures aimed at achieving the goals of effective use of staff (including management and intellectual capabilities) and intelligence.

Methodological structural and functional characteristics of intellectual capital of the enterprise involves its decomposition into such components as (1) innovative (including intellectual-creative) activities, (2) technical and technological support, (3) staff availability and structure, (4) staff stability, (5) labor productivity and efficiency, (6) social security, (7) staff development.
In the process of intellectual capital formation, the management of the tourism infrastructure enterprises solves problems related to staffing needs for highly qualified specialists, compliance with personnel education, qualifications, gender, age, professional and competence characteristics, organization of labor, cost-effectiveness and productivity, growth of professional qualification level of staff, active training, management and implementation of the results of innovation programs of enterprise development and intellectual-creative activities.

Innovative development and strengthening of customer orientation by the tourism infrastructure enterprises requires an adequate resource base that can ensure a high level of efficiency in the implementation and capitalization of innovations in the market. Despite the strategically important role of financial resources in supporting the processes of development and expanded reproduction of an enterprise, the core of ensuring the effectiveness of its innovation activities is the availability of highly professional intellectual capital. After all, intellectual personnel manage the implementation of an innovative project at all stages, including the emergence of innovation ideas and its implementation in practice. The lack of intellectual capital in the tourism infrastructure enterprises increases the risks of unprofitability of an innovative project, provokes systemic project errors, and complicates the process of implementing an innovative business product. On the other hand, the improvement of intellectual capital of the tourism infrastructure enterprises should be focused on improving the principles of personnel policy; rationalization of methods for staff selection, placement and career growth; optimization of approaches to training, retraining and development of intellectual personnel; balancing tangible and intangible forms of intellectual work motivation.

The formation of intellectual capital in the tourism infrastructure enterprises requires its adequate resource support in terms of the following components: (1) management support; (2) financial support; (3) resource and material support; (4) scientific and infrastructural support; (5) information and communication support.

Intellectual staff is a specific category of employees for whom it is important to have comfortable employment conditions in the enterprise and public recognition of the results of their work.

In turn, this requires the formation of an atmosphere of mutual trust not only among the team, but also, above all, in the system of relations "manager-subordinate". For employees of the innovation 
sphere and for customer orientation it is important to have a high level of trust in the team, the power to make managerial decisions and provide the management of innovation activities, the ability to freely experiment and implement innovative projects in business practice. Such prerequisites form a sense of responsibility and social importance of the results of innovation activities of intellectual staff, which improves satisfaction of their interests and needs in terms of self-affirmation and self-realization in the team.

The specificity of intellectual work is that its results should generate qualitatively new unique knowledge, in the process of transformation of which the innovation products and projects of customer-oriented development should be formalized. In turn, the implementation of the latter should lead to strengthening the competitive position of enterprises, increasing the efficiency of their business processes, improving customer satisfaction, gaining economies of scale and implementing expanded business reproduction. The paradox is that the results of hours actually worked do not always generate intellectual knowledge that can be transformed into innovative projects. In addition, intellectual work can be conducted by only a limited number of employees who possess the necessary intellectual characteristics (scientific and methodological apparatus, abstract and critical thinking, creativity, flexibility, etc.). Such preconditions quite naturally cause differentiation in approaches to organizing corporate personnel policies.
It is obvious that the priorities and tools for improving the intellectual capital of the tourism infrastructure enterprises can be differentiated depending on the specific type of innovation (Table 1).

The formation of adequate intellectual capital of the tourism infrastructure companies involves improving their personnel policy in terms of selection, placement, training, retraining, development, motivation and career growth of staff.

In this regard, it is advisable to focus on the implementation of the following measures:

1) rationalization of processes of search and selection of intellectual personnel in the field of innovative development based on coordination of project purposes with personnel possibilities of the enterprise, optimization of its intellectual-innovative division, dissemination of the practice of public-private co-financing of personnel training in higher education institutions, intensification of cooperation with staffing agencies and regional network of the State Employment Service institutions;

2) revision of the established principles and bases of placement of intellectual personnel by coordinating the skills of the employee with direct job responsibilities, optimizing the management structure and balancing the organizational structure of the enterprise, continuous staff rotation to ensure its development and minimize the risk of potential violations and abuses in the process of innovation customer-oriented activities;

Priorities and tools for improving the intellectual capital of the tourism infrastructure entities

\begin{tabular}{|l|l|l|}
\hline Innovation type & \multicolumn{1}{|c|}{ Policy priorities } & \multicolumn{1}{c|}{ Tools for achieving priorities } \\
\hline $\begin{array}{l}\text { Service and } \\
\text { product }\end{array}$ & $\begin{array}{l}\text { Requires a strategic focus on } \\
\text { improving competencies in the field } \\
\text { of process regulations for customer } \\
\text { service. }\end{array}$ & $\begin{array}{l}\text { Carrying out the communication } \\
\text { for sharing innovative experiences, } \\
\text { identification of consumer needs } \\
\text { and estimation of solvent demand } \\
\text { in the market. }\end{array}$ \\
\hline $\begin{array}{l}\text { Organizational } \\
\text { and managerial }\end{array}$ & $\begin{array}{l}\text { Provides for the development of } \\
\text { organizational and managerial } \\
\text { abilities and skills of employees, } \\
\text { the implementation of which allows } \\
\text { adopting innovations in management. }\end{array}$ & $\begin{array}{l}\text { Involvement of consulting and auditing } \\
\text { companies in management, approval } \\
\text { of the practice of systematic rotation } \\
\text { of management staff. }\end{array}$ \\
\hline Market & $\begin{array}{l}\text { Requires the formation of intellectual } \\
\text { knowledge on advanced technologies } \\
\text { for the promotion of innovative } \\
\text { products on the market. }\end{array}$ & $\begin{array}{l}\text { Involvement of employees } \\
\text { in organizing and conducting } \\
\text { the research concerning business } \\
\text { development, its niche segments } \\
\text { and parameters. }\end{array}$ \\
\hline Technological & $\begin{array}{l}\text { Development of design and } \\
\text { engineering skills of employees } \\
\text { and strengthening of project and } \\
\text { technological component of training. }\end{array}$ & $\begin{array}{l}\text { Formation of a joint material } \\
\text { and technical base for the project- } \\
\text { experimental activities in the sphere } \\
\text { of innovation and technology. }\end{array}$ \\
\hline
\end{tabular}


3) improvement of approaches to the organization of training and retraining of intellectual personnel through using the practice of conducting systematic training at the enterprise, mandatory internships in leading research and innovation centers;

4) formation of favorable conditions for comprehensive development and self-improvement of intellectual personnel based on the provisions of liberal-democratic management style, ensuring opportunities for career growth and self-affirmation in the team, quick solving and response to conflict situations to prevent their spread in the enterprise and destructive effects on the processes of forming a healthy moral and psychological working conditions;

5) organization of a comprehensive system for monitoring and diagnosing the effectiveness of intellectual and personnel support for the enterprise by ensuring continuous collection of target data with the use of modern methods of its verification, developing an adaptive system of quantitative and qualitative indicators for evaluating labor efficiency in the sphere of innovation, involvement of outsourcing companies in projecting strategic directions for increasing the intellectual staff efficiency;

6) improvement of the intellectual personnel motivation system, which provides focus on: the formation of motivation mechanisms for strengthening tangible and intangible incentives to increase the efficiency of human resources based on the growing share of wages in the overall cost structure of innovative products; implementation of mechanisms for improving the motivation of intellectual staff in the innovation sphere by balancing economic, socio-psychological and ergonomic tools; intensification of adoption of the best world practice experiences concerning motivation systems for intellectual staff, as well as developing effective mechanisms for their adaptive use under domestic economic conditions, primarily in terms of balancing tangible and intangible forms of motivation, diversification of funding sources for innovative projects, maintaining and strengthening the intellectual potential of the enterprise;

7) ensuring transparent fair approaches to organizing career growth of intellectual personnel of the enterprise based on shaping conditions for providing fair competition in the workforce, preventing the influence of subjective factors on the decision-making process, implementation of transparent appointment mechanisms.

Conclusions. Thus, the intellectual capital of the tourism infrastructure entities is one of the most important resources and components in the business management system. Its formation and effective use creates the prerequisites for providing the company with personnel capable of generating innovative and intellectual-creative activities, to form a modern logistics and information technology support for business processes. Improving the intellectual capital of the tourism infrastructure enterprises allows strengthening their competitive position and ensuring viability and development under conditions of growing competition and development of the information society.

Structural and functional areas of intellectual capital of the tourism infrastructure enterprises are innovation, technical and technological support, security, staff structure, staff availability, structure, labor productivity and efficiency, social security and staff development. Improving the intellectual capital of the tourism infrastructure enterprises requires restructuring the existing approaches to the implementation of personnel policy of enterprises based on balance, objectivity, rationality and resource efficiency.

Further scientific research in this direction concerns the substantiation of economic and mathematical models of formation and effective use of intellectual capital of tourism enterprises and tourism infrastructure.

\section{REFERENCES:}

1. Vasyltsiv T. G., Shehlovych A. M. and Vasyltsiv V. V. (2017) Finansovo-ekonomichni instrumenty stymulyuvannia rozvytku IT-sfery Ukrainy [Financial and economic instruments of stimulation of development of IT-sphere of Ukraine]. Economic discourse, vol. 4, pp. 128-136.

2. Mihushchenko Yu. V. (2017) Mehanizmy rozvytku turystychnoi galuzi v umovah tymchasovoi okupacii chastyny terytorii Ukrainy [Mechanisms of the development of the tourism industry in conditions of temporary occupation of part of the territory of Ukraine: the regional aspect]. Available at: http://lv.niss.gov.ua/public/File/1/AZ_Mihushchenko_2016.pdf (accessed 10 March 2020).

3. Orlyk I. O., Vasyltsiv T. G. and Rudyk S. A. (2016) Mehanizmy ta zasoby aktyvizaciyi innovaciynogo rozvytku pidpryemstv rozdribnoyi torgivil [Mechanisms and means of intensification of the innovative development of enterprises of retail trade]. Bulletin of Khmelnytsky National University. Economic sciences, vol. 1. pp. 102-109.

4. Vlasiuk O. (2018) System transformations of the national economy: challenges and expectations. Bydgoszcz, Poland: University of Economy Publishing House. 
5. Lupak R. L. (2016) Ocinyuvannia formuvannia konkurentnyh perevag turystychnyh pidpryemstv [Assessment of formation of competitive advantages of tourist enterprises]. Bulletin of the Khmelnytsky National University, vol. 3, pp. 189-194.

6. Holod A. (2017) Bezpeka regionalnyh turystychnyh system: teoriya, metodologiya ta problemy garantuvannia [Bezpeka rehionalnykh turystychnykh system: teoriya, metodolohiya ta problemy harantuvannya]. Lviv: LDUFK.

7. Melnychenko O. A. and Shvedun V. O. (2017) Osoblyvosti rozvytku industriyi turyzmu v Ukrayini [Features of the development of the tourism industry in Ukraine]. Kharkiv: NUTSZU.

8. Okhrimenko A. H. (2011) Problemy konkurentospromozhnosti turystychnoyi galuzi Ukrainy [Problems of Competitiveness of the Tourist Industry of Ukraine]. Investytsiyi: praktyka ta dosvid, vol. 5, pp. 42-47.

9. Dymchuk A. V. (2010) Formuvannia turystychnoyi polityky derzhavy v umovah dynamichnyh zmin rynkovogo seredovashcha [Formation of the tourist policy of the state in conditions of dynamic changes in the market environment]. Ekonomika ta derzhava, vol. 12, pp. 44-45.

10. Levytska O. (2010) Sutnist', henezys ta evolyutsiya ponyattya "lyuds' ki resursy": systemno-kontseptual'nyy pidkhid [The essence, genesis and evolution of the concept of "human resources": a system-conceptual approach]. Ukraina: aspekty pratsi, vol. 1, pp. 37-42.

11. Mulska O. P., Levytska O. O., Kutsyk V. I. (2020) Derzhavna polityka zabezpechennya innovatsiynykh form zaynyatosti v umovakh tsyfrovizatsiyi ekonomiky [State policy of maintaining the innovative forms of employment in the context of the economy digitalization]. Rehional'na ekonomika, vol. 3, pp. 81-90.

\section{СПИСОК ВИКОРИСТАНИХ ДЖЕРЕЛ:}

1. Васильців Т. Г., Шехлович А. М., Васильців В. В. Фінансово-економічні інструменти стимулювання розвитку IT-ссрери України. Економічний дискурс. 2017. № 4. С. 128-136.

2. Мігущенко Ю. В. Механізми розвитку туристичної галузі в умовах тимчасової окупації частини території України: регіональний аспект : аналіт. записка. URL: http://lv.niss.gov.ua/public/File/1/AZ_Mihushchenko_2016.pdf

3. Орлик І. О., Васильців Т. Г., Рудик С. А. Механізми та засоби активізації інноваційного розвитку підприємств роздрібної торгівлі. Вісник Хмельницького національного університету. Економічні науки. 2016. № 1. C. $102-109$.

4. System transformations of the national economy: challenges and expectations : collective monograph I edited by O. Vlasiuk and other. Bydgoszcz, Poland : University of Economy Publishing House, 2016. Vol. 1. 357 p.

5. Лупак Р. Л. Оцінювання формування конкурентних переваг туристичних підприємств. Вісник Хмельницького національного університету. 2016. № 3. С. 189-194.

6. Голод А. Безпека регіональних туристичних систем: теорія, методологія та проблеми гарантування : монограсрія. Львів : ЛДУФК, 2017. 340 с.

7. Мельниченко О. А., Шведун В. О. Особливості розвитку індустрії туризму в Україні : монограсрія. Харків : Вид-во НУЦЗУ, 2017. 153 с.

8. Охріменко А. Г. Проблеми конкурентоспроможності туристичної галузі України. Інвестиції: практика ma досвї. 2011. № 5. С. 42-47.

9. Димчук А. В. Формування туристичної політики держави в умовах динамічних змін ринкового середовища. Економіка та держава. 2010. № 12. С. 44-45.

10. Левицька О. Сутність, генезис та еволюція поняття “людські ресурси": системно-концептуальний підхід. Україна: аспекти праці. 2010. № 1. С. 37-42.

11. Мульска О. П., Левицька О. О., Куцик В. І. Державна політика забезпечення інноваційних форм зайнятості в умовах цифрровізації економіки. Регіональна економіка. 2020. № 3(97). С. 81-90. 